\title{
SEMIOTIKA DALAM SYAIR AHO SEGALA KITA YANG BERNAMA INSAN KARYA HAMZAH FANSURI
}

\author{
Imarafsah Mutianingtyas \\ Universitas Gadjah Mada \\ Pos-el: imarafsahmutian@gmail.com
}

Diserahkan: 30 Juli 2020, Direvisi: 30 Oktober 2020, Diterima: 11 Februari 2021

\begin{abstract}
This study aims to reveal the meaning of the poetry Aho All We Called Insan by Hamzah Fansuri with a semiotic approach. The poem is included in Ruba'i Hamzah Fansuri. Hamzah Fansuri was known as a figure of Sufism scholars during his lifetime, which he later expressed his Sufi ideas with literature. He wrote many poems that contain elements of spirituality. The poems he wrote became the pioneers of classical Malay literature, namely at the end of the 16th century when the kingdom of Aceh Darussalam reached its heyday. Poem Aho All We Named People, from the title that calls Insan, which means human. It is said that humans as living things in the world always have a relationship with the Creator. This poem also reminds us that humans are turned on and will die at the appointed time by the Creator. Thus, the poem contains advice and guidance on how to become a civilized human being. So to achieve the objectives of the study, the poem will be examined and its significance revealed by the heuristic and hermeneutic reading method. This research is qualitative. The data source of this research is the poetry Aho All We Named
\end{abstract}


People and references literature related to literature, semiotics, hermeneutics, and Sufism. The results of data analysis in this study are then presented in a descriptive narrative.

Keywords: Hamzah Fansuri, Poetry, Semiotics

\begin{abstract}
Abstrak
Penelitian ini bertujuan untuk mengungkapkan makna syair Aho Segala Kita yang Bernama Insan karya Hamzah Fansuri dengan pendekatan semiotika. Syair tersebut termasuk dalam Ruba'i Hamzah Fansuri. Hamzah Fansuri dikenal sebagai tokoh ulama tasawuf semasa hidupnya, yang kemudian ia mengekspresikan gagasan tasawuf tersebut dengan bersastra. Ia menuliskan banyak syair yang mengandung unsur kerohanian. Syair-syair yang ditulisnya menjadi pelopor kesusastraan Melayu klasik, yaitu pada penghujung abad ke-16 ketika kerajaan Aceh Darussalam mencapai masa kejayaannya. Syair Aho Segala Kita yang Bernama Insan ini, dari judulnya yang menyebut Insan, yang artinya manusia. Dikisahkan bahwa manusia sebagai makhluk hidup di dunia selalu memiliki hubungan dengan Sang Pencipta. Syair ini juga mengingatkan bahwa manusia dihidupkan kemudian akan mati di waktu yang telah ditentukan Sang Pencipta. Dengan demikian, syair tersebut mengandung nasihat dan tuntunan bagaimana seharusnya menjadi manusia yang beradab. Maka untuk mencapai tujuan penelitian, syair tersebut akan diteliti dan diungkapkan maknanya dengan metode pembacaan secara heuristik dan hermenutik. Penelitian ini bersifat kualitatif. Sumber data penelitian ini adalah syair Aho Segala Kita yang Bernama Insan dan refrensi kepustakaan yang berkaitan dengan sastra, semiotika, hermeneutika, dan tasawuf. Hasil analisis data dalam penelitian ini kemudian disajikan secara naratif deskriptif.
\end{abstract}

Kata Kunci: Hamzah Fansuri, Syair, Semiotika 


\section{PENDAHULUAN}

Kesusastraan Melayu Klasik mulai berkembang pada penghujung abad ke-16 di Aceh, yaitu ketika kerajaan Aceh Darussalam mencapai masa kejayaannya di bawah pimpinan Sultan Alaudin Ri'ayat Syah Sayid al-Mukammil. Seorang ulama tasawuf terkemuka bernama Hamzah Fansuri mengungkapkan gagasan tasawufnya dengan mengarang beberapa kitab dan menggubah syair tasawuf dengan kesastraan yang indah (Zakaria, 2016: 18). Menurut teori dakwah, Natsir (dalam Zakaria, 2016: 18) menjelaskan perihal seorang menyampaikan dakwah adalah bagaimana menentukan cara yang tepat dan efektif dalam menghadapi suatu kondisi masyarakat tertentu. Demikianlah, seorang pendakwah harus mengenali karakter dan tahu bagaimana kondisi masyarakat tersebut demi kelancaran berdakwah. Penggubahan isi kitab menjadi syair tersebut dilakukan Hamzah Fansuri sebagai bentuk strategi dakwah.

Syair gubahan Hamzah Fansuri yang mengandung ajaranajaran tasawuf memiliki pengaruh yang sangat kuat di wilayah Nusantara pada waktu itu. Akhirnya, pada awal abad ke-17, ketika Sultan Iskandar Muda menjadi pemimpinnya, datanglah ulama dari India yang dikenal dengan nama Nurrudin Araniri. Hadi (1983: 13) menjelaskan bahwa Araniri adalah seorang yang tidak menyukai ajaran taswuf Hamzah Fansuri. Araniri juga berhasil memengaruhi sultan sehingga kemudian terjadilah peristiwa pembakaran karyakarya Hamzah Fansuri dan pemusnahan ajaran tasawufnya.

Peristiwa pembakaran tersebut melenyapkan banyak naskah Hamzah Fansuri, namun masih ada naskah-naskah yang berhasil diselamatkan oleh muridnya. Sangidu (2016: 308) menjelaskan bahwa karya-karya Hamzah Fansuri tak terhitung banyaknya, baik prosa maupun puisi. Naskah yang berhasil diselamatkan pun sudah rapuh dimakan zaman dan kutu buku. Salah sebuah naskah yang terselamatkan adalah naskah $R u b a^{\prime} i$, yang salah satu syairnya berjudul Aho Segala Kita yang Bernama Insan akan dibahas dalam tulisan ini. 
Syair Aho Segala Kita yang Bernama Insan terdiri atas 15 bait. Masing-masing baitnya terdiri dari 4 baris yang menyerupai pantun namun tidak selalu memiliki persajakan. Antara bait satu dan yang lain, masing-masing memiliki gagasannya sendiri-sendiri. Namun, bila telah dimaknai secara utuh maka sebenarnya masing-masing bait itu adalah sebuah penjelasan yang lebih detil terhadap suatu gagasan utama yang diangkat dalam syair.

Syair Aho Segala Kita yang Bernama Insan, sebagaimana judulnya yang menyebutkan Insan, maka syair ini bercerita tentang manusia. Manusia dan siapa yang menciptakan manusia, bagaimana manusia bersikap kepada penciptanya, bagaimana manusia menjadi manusia yang dekat tanpa sekat dengan penciptanya, bagaimana penciptanya mencipta kehidupan dan ilmu-ilmu di alam raya, bagaimana aturan dan adab menjadi manusia.

Syair Aho Segala Kita yang Bernama Insan ditulis dengan bahasa Melayu yang di dalamnya terdapat beberapa kata yang menggunakan bahasa Arab, dan kutipan pepatah dalam bahasa Arab pula. Pengaruh kebahasaan ini oleh Rahman (2016: 37) dijelaskan bahwa Hamzah Fansuri tinggal di wilayah yang banyak dikunjungi bangsa asing, termasuk Arab. Selain itu, Hamzah Fansuri juga mengembara ke pelbagai tempat dan pernah mengunjungi Arab. Hamzah Fansuri juga menguasai beberapa bahasa selain Arab, yait bahasa Urdu, Parsi, Melayu, dan Jawa.

Demikianlah syair Aho Segala Kita yang Bernama Insan mengandung istilah-istilah di luar Bahasa Melayu. Istilah kebahasaan, Bahasa Arab, ini yang kemudian peneliti anggap sebagai tanda. Istilah berbahasa arab itu semacam sebagai pesan implisit yang hendak disampaikan dalam sebuah syair. Oleh sebab itu, perlu dipahami makna dari tanda-tanda tersebut.

Berdasarkan pemaparan tersebut, penelitian bertujuan mengungkap makna syair Aho Segala Kita yang Bernama Insan dengan pendekatan semiotika. Pendekatan semiotika dianggap tepat karena semiotika memandang karya sastra memiliki sistem tanda yang bermakna estetik. Interpretasi dapat dilakukan secara 
bebas sejauh memiliki argumen yang jelas dan masuk akal. Dengan demikian, pendekataan semiotika diyakini mampu mengungkap makna untuk mencapai pemahaman utuh atas gagasan yang dikemukakan dalam syair tersebut.

\section{KAJIAN LITERATUR}

Nama Hamzah Fansuri memang termahsyur berkat ajaran tasawuf dan karya-karyanya. Begitu banyak pula penelitian yang telah dihasilkan dari peninggalan karya Hamzah Fansuri. Berikut penelitian yang relevan dengan tulisan ini.

Pertama, penelitian berjudul Rubayat Hamzah Fansuri: Kajian Strukturalisme-Semiotika, yang ditulis oleh Medri Osno (2016). Penelitian tersebut memaparkan bentuk struktur bahasa melalui sistem pemakaian diksi dalam proses sosial dan pemaknaan karya secara semiotika melalui pembacaan heuristik dan hermeneutik. Dalam penelitian tersebut Osno (2016: 93) menyimpulkan bahwa keseluruhan Rubayat Hamzah Fansuri penuh dengan ironi dan hiperbola. Kedua hal tersebut untuk menimbulkan daya tarik sajak atau untuk membuat aneh.

Kedua, penelitian berjudul Sufisme dalam Syair Hamzah Fansuri yang ditulis oleh Haryadi (2012). Hasil penelitiannya mengungkapkan bahwa visi ketuhanan Hamzah Fansuri sama dengan sufi lainnya yaitu mendekatkan diri sedekat-dekatnya kepada Tuhan. Hamzah Fansuri memiliki pandangan bahwa dunia sebagai sesuatu yang fana, sedangkan yang kekal atau baka adalah akhirat. Penelitian ini bermanfaat sebagai refrensi landasan berpikir untuk membaca dan memaknai syair yang menjadi objek material penelitian ini.

Ketiga, penelitian berjudul Sidang Fakir Empunya Kata Karya Syaikh Hamzah Fansuri: Kajian Filologi dan Analisis Semiotik, yang ditulis oleh Sangidu (2002). Hasil penelitiannya mengungkap bahwa semiotika sebagai teori dan metode berhasil untuk menjelaskan makna dan kandungan syair Sidang Fakir Empunya Kata. Berdasarkan hasil penelitiannya, tujuan penciptaan syair tersebut adalah untuk 
menceritakan Allah sesuai dengan pengalaman batin yang dialami Hamzah Fansuri. Syair tersebut sebagaimana diungkapkan Sangidu (2002: 316) bahwa Allah terlalu nyata daripada semua hal yang nyata. Keadaan nyata tersebut bukan untuk dilihat dengan mata kepala, melainkan mata hati. Oleh karena itu, hati seseorang haruslah suci supaya terhindar dari sifat buruk.

Keempat, penelitian berjudul Ikan Tunggal Bernama FÂDHIL Karya Syaikh Hamzah Fansuri: Analisis Semiotik, yang ditulis oleh Sangidu (2003). Penelitian ini menjelaskan tentang makna teks dalam syair, yakni hubungan antara manusia dengan penciptanya. Sebagaimana yang dijelaskan bahwa wujud Allah itu sama dengan wujud alam semesta dan seisinya. Manusia sebagai salah satu wujud ciptaannya harus berusaha untuk bisa menyatu dengan Tuhan. Untuk bisa menyatu dengan Tuhan, maka manusia harus belajar kepada guru yang ilmunya sempurna (Sangidu, 2003: 198). Keadaan ini dapat diartikan dengan manusia menjauhi hal-hal tentang duniawi.

\section{METODE PENELITIAN}

Penelitian ini menggunakan metode penelitian kualitatif, dengan pemaparan hasil penelitian secara naratif deskriptif. Objek penelitian ini adalah syair berjudul Aho Segala Kita adalah Insan karya Hamzah Fansuri. Subjek penelitian adalah pemaknaan syair secara semiotik.

Data primer penelitian ini mencakup seluruh kosakata yang terdapat di dalam syair berjudul Aho Segala Kita adalah Insan karya Hamzah Fansuri. Data sekunder mencakup teks-teks berupa buku dan jurnal yang berkaitan dengan tujuan pembahasan dalam penelitian ini.

Analisis data berdasarkan pada data primer dan data skunder yang dilakukan dengan pendekatan semiotika dan ditelaah dengan pembacaan secara heuristik dan hermeneutik. Pembacaan heuristik menurut Pradopo (th: 340) adalah pemahaman semiotik tingkat 
pertama. Sedangkan hermeneutik merupakan pemberian makna, pembacaan berdasar sistem tanda semiotik tingkat kedua.

Pembacaan heuristik merupakan pemahaman arti bahasa berdasarkan konvensi suatu bahasa, kemudian pembacaan hermeneutik merupakan pemaknaan dan penafsiran atas pembacaannya (Osno, 2016: 77). Demikian, dimaksudkan untuk bisa mengungkapkan makna sebagaimana tujuan penelitian ini.

Pendekatan semiotika digunakan karena syair bermediumkan bahasa. Menurut Teeuw (1984: 96) bahasa merupakan sistem tanda. Bahasa termasuk dalam semiotik karena mengandung lambanglambang (Luxemburg, 1992: 44-47). Semiotika menawarkan cara pandang terhadap tanda-tanda yang sistematis, yang bebas tafsir. Setiap tanda boleh ditafsirkan sejauh ada pertanggungjawaban berupa argumentasi yang jelas dan dapat diterima oleh akal pikiran.

\section{HASIL PENELITIAN DAN PEMBAHASAN}

Sebagaimana yang telah dikemukakan dalam pendahuluan bahwa penelitian ini memiliki satu buah rumusan masalah yaitu bagaimana makna yang terkandung dalam syair Aho Segala Kita yang Bernama Insan karya Hamzah Fansuri. Maka berikut ini dipaparkan jawaban beserta analisisnya terhadap rumusan masalah tersebut.

\section{Bait Pertama}

Aho segala kita yang bernama insan

Jangan taqshìr mengaji Qur'an

Karena di sana sekalian firman

Menyatakan di dalamnya 'iyan

Makna 'Aho' dalam syair ini sebagai sebuah sapaan, seperti 'wahai' atau 'duhai'. Jadi, pada baris pertama merupakan sapaan Hamzah Fansuri kepada 'Insan' atau umat sebagai pevcmbaca, 'wahai/duhai manusia. Baris kedua, "Jangan taqshīr mengaji Qur’an”. Taqshìr artinya memperpendek. Jadi, dapat diartikan bahwa jangan setengah-setengah bila mengaji Al Qur’an. Seperti halnya ketika kita mengerjakan sesuatu tapi tidak selesai, maka hasilnya tidak akan 
bagus. Demikian pula bila mengaji Al Qur'an tidak tuntas, seperti hanya membaca ayat dan terjemahannya tanpa membaca tafsir ayat, maka tentu akan tidak sampai pada pemahaman yang tepat.

Pada baris ketiga dikatakan, "Karena di sana sekalian firman", artinya di dalamnya terdapat firman atau pesan Allah. Pesanpesan yang dimaksudkan itu dijelaskan dalam baris keempat yang, "Menyatakan di dalamnya 'iyan". Kata 'iyan berarti mata. Mata merupakan panca indera manusia yang berguna untuk melihat. Ketika melihat sesuatu, maka akan menyadari keberadaan sesuatu tersebut. Selain itu, mata juga berkenaan dengan hati, mata hati, artinya memliki perasaan yang lembut. Maka dalam baris tiga dan empat ini dapat diartikan pesan-pesan dalam Qur'an itu dapat menyadarkan manusia, menjadikan hati manusia lembut, dan menghindarkannya dari jalan yang tidak dikehendaki Pencipta.

Maka pada bait pertama ini dapat dimaknai kandungan syairnya bahwa sebagai manusia, alangkah baiknya mengaji Qur’an dengan memahami sungguh-sungguh bacaannya, sebab di dalam Qur'an terdapat pesan-pesan Allah yang menjadi penuntun hidup bagi manusia.

\section{Bait Kedua}

Fardhu dan sunat yogya kaupakai

Akan lima waktu jangan kaulalai

Halal dan haram faraghkan bapai

Itulah amal yang tiada berbagai

Baris pertama, "Fardhu dan sunat yogya kaupakai", yogya artinya patut, layak, baik, sehingga pesan dalam bait satu ialah bahwa menunaikan ibadah wajib dan sunnah adalah baik. Terutama sebagaimana disampaikan di baris kedua, "Akan lima waktu jangan kaulalai", artinya jangan melalaikan salat lima waktu. Baris ketiga, "Halal dan haram faraghkan bapai". Faragh artinya selesaikan atau tinggalkan, artinya harus menjauhi hal-hal yang diharamkan oleh ajaran. Baris keempat sebagai kalimat yang mempertegas tiga baris sebelumnya, bahwa beribadah kepada Allah akan menjaga dan menjauhkan manusia dari hal-hal tercela. 
Maka bait kedua ini dapat dimaknai kandungan syairnya bahwa ibadah baik sunah maupun wajib alangkah baiknya dilaksanakan dan tidak menunda-nunda. Terutama ibadah lima waktu. Ketika seseorang menjalankan ibadah dengan taat, maka ibadah tersebut akan membentengi dirinya dari perbuatan yang tidak baik. Seseorang akan menjauhi hal-hal yang diharamkan dalam aturan agamanya. Namun, bila seseorang lalai sehingga ia terjerumus mengonsumsi sesuatu yang haram, baik cara memperoleh harta maupun apa yang ia makan, maka ada pula ganjaran untuknya. Sebagaimana Rasulullah Saw. mengingatkan, "Demi zat yang menguasai diriku, jika seseorang mengonsumsi harta yang haram, maka tidak akan diterima amal ibadahnya selama 40 hari." [HR Thabrani].

\section{Bait Ketiga}

Sunat Muhammad terlalu 'azhìm

Barang memakai dia bernama sālim

Karena rasul Allah sempurna chākim

Menunjukkan jalan ke jannatun-na'ìm

Baris pertama, "Sunat Muhammad terlalu 'azhìm", 'azhìm artinya agung. Maksudnya adalah bahwa sunat yang diajarkan Muhammad itu berasal dari ilmu yang agung, ilmu dari Tuhan. Baris kedua, "Barang memakai dia bernama sālim", sālim artinya selamat. Maksudnya ilmu yang agung itu akan menyelamatkan manusia. Keselamatan yang dimaksudkan adalah keselamatan di dunia dan akhirat. Ketika masih hidup, seseorang yang berilmu akan senantiasa berbuat baik dan menunaikan amal. Amalan itulah yang kelak akan menyelamatkannya di akhirat.

Baris ketiga, "Karena rasul Allah sempurna chākim", chākim artinya bijak. Maksudnya bahwa ilmu yang diajarkan Muhammad itu mengajarkan sikap bijak sebagai manusia. Hal tersebut tertuang dalam ayat-ayat Qur'an yang merupakan mukjizat dan tidak ada yang bisa menandingi. Sebagaimana surah Al-Israa ayat 88, yang artinya, "Katakanlah, "Sesungguhnya jika manusia dan jin berkumpul untuk 
membuat yang serupa (dengan) Al-Qur'ân ini, mereka tidak akan dapat membuat yang serupa dengannya, sekalipun mereka saling membantu satu sama lain."

Baris keempat, "Menunjukkan jalan ke jannatun-na'ìm", jannatun-na'ìm artinya surga kenikmatan. Maksudnya adalah, manusia yang mengikuti sunat Muhammad itu akan berada di jalan yang diridhai sehingga manusia akan dikelilingi kebaikan dan ia akan berbuat baik pula. Dengan demikian, ketika mati amalan semasa hidupnya yang menghantarkan menuju surga dengan segala nikmatnya.

Maka bait ketiga ini dapat dimaknai kandungan syairnya bahwa ajaran Rasulullah Muhammad adalah ajaran yang benar, ajaran yang agung dari Allah Yang Maha Agung. Barang siapa yang mengikutinya maka akan selamat sampai ke surga. Sebagaimana dituturkan bahwa Rasulullah Muhammad adalah nabi terakhir yang menyempurnakan ajaran sebelumnya, dan mukjizat Al-Qur'an adalah kitab yang menyempurnakan kitab-kitab sebelumnya.

\section{Bait Keempat}

Syariat itu ambilkan qandil

Supaya engkau menjadi khalīl

Karena ia datang daripada rabbul-jalī

Menyatakan Allah dan hakikat sabil

Baris pertama, "Syariat itu ambilkan qandil", qandil artinya lampau, yang telah berlalu. Maksudnya, ajaran Rasulullah Muhammad itu ada untuk menyempurnakan ilmu yang ada sebelumnya, dan membawa nasihat untuk hidup ke depan lebih baik. Baris kedua, "Supaya engkau menjadi khalill, khalil artinya kekasih. Menyambung dengan baris pertama, artinya ketika manusia mengikuti ajaran yang disampaikan Rasulullah Muhammad maka ia adalah kekasih Rasulullah karena ia akan dekat dengan Allah. Hal tersebut dijelaskan melalui baris ketiga dan keempat, "Karena ia datang daripada rabbul-jalìl", rabbul-jalīl artinya Tuhan Maha 
Agung. Baris keempat, "Menyatakan Allah dan hakikat sabil", sabil artinya jalan menuju Tuhan.

Maka bait keempat ini dapat dimaknai kandungan syairnya bahwa syariat yang diajarkan Rasulullah Muhammad berasal dari ajaran sebelumnya yang telah disempurnakan oleh Allah dan diturunkan lewat Al-Quran. Ajaran itu dimaksudkan supaya umat manusia menjadi kekasih Allah, karena Allah Maha Agung. Ajaran yang disampaikan Rasulullah Muhammad adalah jalan menuju Tuhan.

\section{Bait Kelima}

Syariatnya itu terlalu ghālib

Minal-masyāriq ilal-maghārib

Kafir dan musyrik sekalian $t a \bar{\imath} i b$

Daripada mulutnya dāim munkirnya ghäib

Baris pertama, "Syariatnya itu terlalu ghālib", ghālib artinya lumrah. Makasudnya adalah ilmunya sangat banyak, diibaratkan dalam baris kedua, "Minal-masyāriq ilal-maghärib" artinya dari timur ke barat. Maksudnya adalah ilmu yang terkandung dalam Al-Quran sungguh luas. Al-Quran mengandung di antaranya ilmu tentang hukum, akidah, dan pesan-pesan moral yang disampaikan melalui kisah-kisah nabi dalam perjuangannya berdakwah, juga nasihat sebagai bekal masa mendatang. Baris ketiga, "Kafir dan musyrik sekalian $t \vec{a} i b$ ", $t \vec{a} i b$ artinya taubat. Maksudnya ialah ajaran Al-Quran itu membawa suatu kaum menuju jalan taubat. Baris keempat, "Daripada mulutnya däim munkirnya ghäib", däim artinya selamanya dan $g h \bar{a} i b$ artinya gaib atau tidak ada. Artinya ucapan yang ingkar itu tidak ada manfaatnya atau omong kosong (para kaum sebelum taubat).

Maka bait kelima ini dapat dimaknai kandungan syairnya bahwa ilmu di dunia ini begitu lumrah, banyak seumpama membentang dari timur hingga barat dan Al-Qur'an mengandung banyak sekali pesan. Demikian, syariat atau ajaran yang dibawa Rasulullah Muhammad ini begitu lumrah. Kekuatan ilmu 
tersebut dapat menyelamatkan dan membuat orang bertaubat. Menyelamatkan umat dari perkataan yang tidak benar atau fitnah, perbuatan musyrik, dan perilaku orang-orang yang kafir sebagaimana terjadi di zaman jahiliyah.

\section{Bait Keenam}

Barang siapa munkir daripada $u s t a d z$

Menjadi kafir, thaghau fil-bilad

Fa aktsarul-fasad

Seperti kaum Tsamud lagi dan 'Ad

Baris pertama, "Barang siapa munkir daripada ustadz", ustadz artinya guru. Guru yang dimaksud dalam bait ini adalah Rasulullah Muhammad. Baris kedua, "Menjadi kafir, thaghau fil-bilad", thaghau fil-bilad artinya memberontak di negara. Memberontak yang dimaksudkan adalah menentang kuasa Allah, dijelaskan di baris ketiga, "Fa aktsarul-fasad" artinya maka kian banyak kerusakan (iman dan moral). Baris keempat, "Seperti kaum Tsamud lagi dan 'Ad'. Tsamud dan 'Ad adalah kaum yang mengingkari Tuhan dan bersikap sombong. Allah berfirman tentang kisah kaum 'Ad, "Dan itulah (kisah) kaum 'Ad yang mengingkari tanda-tanda (kekuasaan) Tuhan. Mereka mendurhakai rasul-rasul-Nya dan menuruti perintah semua penguasa yang sewenang-wenang lagi durhaka." (Q.S Hud ayat 59)

Sedangkan kaum Tsamud adalah sekelompok kaum yang sangat cerdas dalam bidang arsitektur. Namun kesombongan mereka membuat dirinya hancur. Kisah tentang kaum Tsamud yang sombong dan menentang Allah terdapat dalam Q.S Hud ayat 61 yang berarti, "dan kemada kaum Tsamud (Kami utus) saudara mereka, Saleh. Dia berkata, "Wahai kaumku! Sembahlah Allah, tidak ada Tuhan bagimu selain Dia. Dia telah menciptakanmu dari bumi (tanah) dan menjadikanmu pemakmurnya, karena itu memohon ampunan kepada-Nya, kemudian bertobatlah kepada-Nya. Sesungguhnya Tuhanku sangat dekat (rahmat-Nya) dan memperkenankan (doa hamba-Nya)." 
Maka bait keenam ini dapat dimaknai kandungan syairnya bahwa apabila manusia mengingkari ajaran Rasulullah Muhammad, maka ia akan menjadi tersesat dalam tipu daya dunia atau seperti miskin ilmu pengetahuan, tidak berakal. Demikian orang-orang yang tak berilmu itu akan memberontak dan membuat kerusakan di muka bumi. Padahal ketika manusia membuat kerusakan di bumi, sama seperti halnya dia sedang menghancurkan dirinya sendiri karena bumi adalah tempat hidupnya, lantas di mana akan ada kehidupan bila tempat hidup dihancurkan?

\section{Bait Ketujuh}

Jika telah kauturut Syariatnya

Mangka kaudapat asal tarikatnya

Ingat-ingat akan hakikatnya

Supaya tahu akan makrifatnya

Baris pertama, "Jika telah kauturut Syariatnya" maksudnya adalah apabila manusia mengikuti ajaran yang dibawa oleh Rasulullah Muhammad, maka ia akan memperoleh tarikat yang berarti jalan, sebagaimana dalam baris kedua, "Mangka kaudapat asal tarikatnya." Jalan yang dimaksud adalah jalan yang lurus, menuju kebaikan dan surga. Baris ketiga, "Ingat-ingat akan hakikatnya", artinya adalah ketika manusia telah ada di jalan yang baik itu, diharapkan selalu mengingat ajaran itu supaya; pada baris keempat, "Supaya tahu akan makrifatnya”, makrifat yang berarti laku menuju jalan tuhan, maksudnya adalah taat ibadah. Maka bait ketujuh ini dapat dimaknai kandungan syairnya bahwa apabila manusia mengikuti petunjuk Allah melalui ajaran Rasulullah Muhammad, niscaya ia berada di jalan yang lurus. Akan menjadi manusia yang beradab dan taat kepada Allah sehingga ia akan selamat hingga akhirat.

\section{Bait Kedelapan}

Makrifat itu sempurna 'áli

Pada sekalian Islam terlalu dha'if

Itulah ilmu yogya kaucari

Supaya jadi engkau ruhani 
Baris pertama menjelaskan tentang makrifat, yang disebutkan, "Makrifat itu sempurna 'āli” yang mana 'āli artinya tinggi. Maksudnya adalah sebaik-baiknya hidup adalah yang berada dalam kebaikan atau jalan Tuhan. Baris kedua, "Pada sekalian Islam terlalu dha'if", dha'if artinya lemah. Maksudnya adalah bila tidak dengan berislam, maka dengan apa lagi? Bahwa Islam adalah yang menguatkan. Baris ketujuh mengatakan bahwa itulah (Islam) adalah ilmu yang patut. Baris kedelapan memberi penegasan, "Supaya jadi engkau ruhani" ruhani artinya jiwa. Maksudnya adalah manusia supaya memiliki jiwa yang kuat dan perasaan yang senantiasa damai.

Maka bait kedelapan ini dapat dimaknai kandungan syairnya bahwa sesungguhnya manusia adalah makhluk yang lemah bila ia tidak mempelajari Islam secara sungguh-sungguh dan menyeluruh. Lemah diartikan sebagai lemah iman, dan mudah tergoda bisikan setan. Ilmu dalam syariat Islam ialah yang patut dicari dan dipelajari supaya iman menjadi teguh dan jiwa menjadi damai karena berada di jalan Allah.

\section{Bait Kesembilan}

Sabda rasulullah: man 'arafa nafsahu

Bahwasanya mengenal akan Rabbahu

Jika sungguh engkau 'abdahu

Jangan kau cari illā wajhahu

Baris pertama, "Sabda rasulullah: man 'arafa nafsahu" yaitu Hamzah mengutip sabda Rasulullah yang artinya, "siapa yang mengenal dirinya", maksudnya adalah manusia yang menyadari bahwa dirinya adalah manusia biasa yang hadir karena ciptaan Tuhan. Sebagaimana dalam baris kedua "Bahwasanya mengenal akan Rabbahu", Rabbahu artinya Tuhannya. Baris ketiga, "Jika sungguh engkau 'abdahu', 'abdahu artinya hambanya. Baris ketiga ini berkaitan dengan baris keempat, "Jangan kau cari illā wajhahu", illā wajhahu artinya kecuali wajahnya. Kedua baris tersebut bila diartikan adalah apabila manusia percaya akan Tuhan, ia tidak perlu mencari tahu wujud Tuhan seperti apa. 
Maka bait kesembilan ini dapat dimaknai kandungan syairnya bahwa, apabila manusia mengenali dirinya sendiri sesungguhnya ia akan mengenali Tuhannya. Apabila manusia percaya dengan keberadaan Tuhan sebagai pencipta, maka seseorang tidak akan mencari tahu bagaimana wujud sosok Tuhan. Karena keberadaan Tuhan bisa dirasakan dengan hati.

\section{Bait Kesepuluh}

Wajah Allah itulah yang asal kata

Pada wujudmu lengkap sekalian rata

Jika anganmu menjadi mata

Mangkanya dapat pandangmu nyata

Baris pertama, "Wajah Allah itulah yang asal kata", yang dimaksud wajah dalam baris tersebut adalah keberadaan Allah, dan asal kata maksudnya adalah ciptaannya. Baris kedua, "Pada wujudmu lengkap sekalian rata”, yang dimaksud adalah bahwa ciptaanNya yang paling sempurna tiada kurang apapun. Baris ketiga, "Jika anganmu menjadi mata", maksudnya angan adalah impian-impian indah di dunia, dan mata adalah indera untuk melihat. Artinya bila manusia memandang dunia ini penuh keindahan dunia, maka memang begitulah adanya. Sebagaimana diungkapkan pada baris keempat, "Mangkanya dapat pandangmu nyata", yang menegaskan bahwa apa yang dilihat manusia adalah kenyataan dunia.

Maka bait kesepuluh ini dapat dimaknai kandungan syairnya bahwa (berkaitan dengan bait kesembilan) Allah adalah dzat Yang Maha Agung. Allah pencipta dunia dan segala yang hidup di dalamnya; menciptakan manusia dan alam yang saling memberi hidup. Mata manusia bisa menyaksikan kenyataan di dunia dengan segala keindahannya, dan sekaligus menjadi saksi bahwa dunia juga penuh dengan godaan. Namun, bila manusia berbekal ilmu, maka ia akan tahu dan memilah mana yang baik dan sesuai dengan jalan Tuhan. 


\section{Bait Kesebelas}

Dirimu itu seperti dzilal

Jangan kaupandang pada waham dan khayyal

Jika pandangmu itu pada rupa jamal

Engkaulah dä’im beroleh wishal

Baris pertama, "Dirimu itu seperti dzilal", dzilal artinya hina. Maksudnya adalah bahwa manusia tercipta dari sesuatu yang hina, yang kotor yaitu sari pati tanah. "Jangan kaupandang pada waham dan khayyal", waham dan khayyal artinya ilusi dan khayalan. Maksud dari ilusi ini adalah bahwa tidak pantas manusia terlalu merasa dirinya paling baik, karena manusia tak luput dari salah dan dosa. "Jika pandangmu itu pada rupa jamal" artinya bagus, indah. Maksudnya adalah apabila merasa diri paling baik dan terlalu mengagungkan keindahan dunia, maka sebenarnya hidup hanyalah semantara. Sebagaimana baris terakhir, "Engkaulah däim beroleh wishal", däंim artinya selamanya dan wishal artinya perantara. Maksudnya adalah segala di dunia ini hanyalah titipan dan hidup manusia hanyalah sementara.

Maka bait kesebelas ini dapat dimaknai kandungan syairnya bahwa syair tersebut mengingatkan kembali bahwa manusia diciptakan berasal dari sesuatu yang kotor, yaitu sari pati tanah. Tanah sebagai sesuatu yang dipijak banyak kaki, mengingatkan bahwa manusia tidak akan ada tanpa tanah. Memang dunia ini penuh keindahan dan tipu daya di dalamnya, juga godaan materi yang berlimpah, namun itu semua hanya ilusi dan sifatnya sementara. Jika manusia terus menerus mengikuti nafsu dunia, maka tidak akan merasa puas.

\section{Bait Kedua belas}

Mūtū qabla an tamūtu

Supaya engkau sampai kepada ya man Huwa
A lastu bi rabbikum dan qālu balà
Di sana dā̇im jangan kausahwa 
Baris pertama, "Mūtū qabla an tamūtu", yang artinya matilah sebelum kalian mati yang sebenarnya. Mati yang dimaksudkan adalah tidur pada waktu malam hari, adalah anjuran untuk istirahat setelah siang hari bekerja. supaya pada dini hari hingga menjelang subuh bisa bangun dari tidur, "Supaya engkau sampai kepada ya man Huwa", ya man Huwa artinya hai Dzat Dia. Artinya supaya bisa beribadah pada sepertiga malam dan subuh di waktu yang tepat. Baris ketiga, "A lastu bi rabbikum dan qālu balā", yang artinya Bukankah Aku Tuhanmu? dan Mereka berkata iya. Artinya mengingatkan bahwa manusia diciptakan Tuhan dan kepadaNyalah memohon perlindungan. "Di sana dä’im jangan kausahwa", dä̀im artinya selamanya. Maksudnya adalah bahwa ketika itu terlaksana setiap hari, maka akan dilindungi selamanya.

Maka bait keduabelas ini dapat dimaknai kandungan syairnya bahwa (melanjutkan dari bait kesepuluh) bahwa bila manusia terkena tipu daya dunia, maka jiwa kemanusiaannya akan mati terlebih dahulu, ia telah melupakan syariat, dan akhirnya ia hanya hidup sebagai manusia yang tidak berdaya karena ingkar kepada Tuhan sebagaimana dalam bait keenam tentang kaum Tsamud dan 'Ad. Maka sebagaimana Q.S Al-Isra ayat 79 "Dan pada sebagian malam, lakukanlah salat tahajud (sebagai suatu ibadah) tambahan bagimu. Mudah-mudahan Tuhanmu mengangkatmu ke tempat yang terpuji”, maka bait kesebelas ini tujuannya untuk mengingatkan manusia harus senantiasa bersyukur atas apa yang didapatkannya.

\section{Bait Ketiga Belas}

Setelah mati hamba yang $d h \bar{a}$ if

Lenyaplah rupa sekalian kathif

Washillah iya dengan Yang lathîf

Ilā abadal-abad menjadi syarîf

Bait ketigabelas ini mengingatkan akan kematian yang sesungguhnya, bukan kematian dalam tidur sebagaimana pada bait kesebelas. Baris pertama, "Setelah mati hamba yang dhä'if", dhä'if artinya lemah. Maksudnya adalah manusia tidak ada apa-apanya di hadapan Tuhan, kecuali bersama amal ibadahnya. Baris kedua, 
"Lenyaplah rupa sekalian kathif", kathif artinya rampas atau rebut, maksudnya adalah ketika manusia mati ia tidak akan membawa materi atau harta yang telah ia kumpulkan selama bekerja sekeras apapun. Baris ketiga, "Washillah iya dengan Yang lathïf”, Washillah artinya perantara, maksudnya adalah kematian adalah perantara atau jalan menuju Yang lathîf, Maha Lembut. "Ilā abadal-abad menjadi syarif', artinya hingga selama-lamanya menjadi mulia. Maksudnya adalah, ketika mausia telah mati, dihadapan Tuhan kelak yang membuatnya mulia selamanya adalah amalannya.

Maka bait ketigabelas dapat dimaknai kandungan syairnya bahwa setelah manusia yang lemah (manusia yang tidak mengikuti syariat) itu mati atau hilang, ia juga akan kehilangan segala hal materi yang dimilikinya, yang ia peroleh dari kerja dunia. Ketika manusia meninggal, ia hanya pergi bersama amal dan ibadahnya. Sebagaimana Allah berfirman, "Wahai manusia! Bertaqwalah kepada Tuhanmu dan takutlah pada hari yang (ketika itu) seorang bapak tidak dapat menolong anaknya, dan seorang anak tidak dapat (pula) menolong bapaknya sedikit pun. Sungguh, janji Allah pasti benar, maka janganlah sekali-kali kamu terperdaya oleh kehidupan dunia, dan jangan sampai kamu terperdaya oleh penipu dalam (mentaati) Allah." Q.S Luqman ayat 33.

\section{Bait Keempat Belas}

Aho segala kamu yang berhati

Yogya kautuntut ilmu yang jati

Jika dapat olehmu makna mati

Engkaulah datang kepada ma'ul-chayati

Baris pertama, "Aho segala kamu yang berhati”, maksudnya adalah Hamzah Fansuri menyapa semua umat manusia, semua manusia memiliki hati. Baris kedua, "Yogya kautuntut ilmu yang jati”, artinya adalah layak bagi manusia menuntut ilmu yang jati. Jati diartikan sebagai ilmu yang kuat, yang benar, yang sungguhsungguh. Baris ketiga, "Jika dapat olehmu makna mati", artinya jika manusia telah belajar dan juga beribadah untuk bersiap menghadapi kematian yang datangnya hanya Tuhan yang tahu, 
maka sesungguhnya manusia berada dalam air yang mengalir. Baris keempat, "Engkaulah datang kepada ma'ul-chayati", ma'ul-chayati artinya air kehidupan. Maksudnya adalah kematian itu misteri illahi dan hanya Tuhan yang tahu. Maka manusia hanya bisa menunggu dan bersiap menghadapi kapanpun.

Maka bait keempat belas ini dapat dimaknai kandungan syairnya bahwa segala manusia diciptakan dengan hati agar dapat bersikap lembut dan merasakan sesuatu tanpa melihat wujud, sebagaimana makna dalam bait kedelapan syair ini. Dan manusia handaknya menuntut ilmu, karena menuntut ilmu termasuk dalam ibadah.

Allah juga telah menetapkan bahwa segala yang hidup akan mati, dan hanya Ia yang tahu waktunya, sebagaimana dalam ayat berikut, "Setiap yang bernyawa akan merasakan mati. Kemudian hanya kepada Kami kamu dikembalikan" (Q.S Al-Ankabut ayat 57).

Manusia tidak mengetahui kapan ia akan meninggal, maka usaha yang dapat dilakukan adalah memperbanyak ibadah dan tetap berada di jalan Allah, sehingga kelak akan mendapat kenikmatan akhirat. Sebagaimana janji Allah, "Dan orang-orang yang beriman dan mengerjakan kebajikan, sungguh, mereka akan Kami tempatkan pada tempat-tempat yang tinggi (di dalam surga), yang mengalir di bawahnya sungai-sungai, mereka kekal di dalamnya. Itulah sebaikbaik balasan bagi orang yang berbuat kebajikan, (yaitu) orang-orang yang bersabar dan bertawakal kepada Tuhannya." (Q.S Al-Ankabut ayat 58-59).

\section{Bait Kelimabelas Belas}

Hamzah Fansuri anak dagang

Melenyapkan dirinya tiada sayang

Jika berenang tiada berbatang

Jika berlabuh tiada pada karang

Baris pertama, "Hamzah Fansuri anak dagang", anak dagang dalam baris ini diartikan sebagai manusia biasa yang juga bisa terlena dalam ingar-bingar dunia. Tapi dalam baris kedua, "Melenyapkan 
dirinya tiada sayang", melenyapkan diartikan sebagai meniadakan diri dalam ingar-bingar dunia, tiada sayang diartikan sebagai tidak apa-apa bila kita hidup tidak ditengah hamparan harta benda. "Jika berenang tiada berbatang", berenang diartikan sebagai sebuah usaha yang dilakukan dengan giat untuk mencapai tujuan, tiada berbatang diartikan sebagai tidak ada bergantung dengan orang lain, mandiri, sunyi. "Jika berlabuh tiada pada karang", berlabuh diartikan telah mencapai tujuan setelah melakukan banyak usaha, tiada pada karang diartikan sebagai tempat yang bukan menjadi tujuan akhir, karena ibarat berenang tujuannya mencapai pulau, maka karang ini adalah halangan sebelum mencapai pulau. Artinya, usaha atau dalam mempelajari ilmu dilakukan sungguh-sungguh.

Maka bait kelimabelas ini dapat dimaknai kandungan syairnya bahwa dalam kehidupan terkadang harus terampil membawakan diri tanpa merepotkan orang lain. Apabila ada suatu tujuan yang ingin dicapai, dapat dicapai dengan cara yang baik dan tidak menciderai pihak lain. Begitu pun saat tiba di tujuan, akan sampai pada hasil yang memuaskan. Tidak setengah-setengah dan tidak berhenti di jalan.

\section{PENUTUP}

Berdasarkan analisis dan pembahasan yang telah dilakukan, demikian Syair Aho Segala Kita yang Bernama Insan karya Hamzah Fansuri ini mengandung pesan mendalam yang ditujukan kepada umat manusia, khsusunya pemeluk agama Islam. Bahwasanya Rasulullah Muhammad adalah nabi terakhir yang bertugas menyempurnakan ajaran sebelumnya, dengan ia dibekali mukjizat Al-Qur'an yang juga sebagai penyempurna kitab-kitab sebelumnya.

Judul syair yang menyebut Insan, yang artinya manusia, memang berkisah tentang menusia; kehidupan manusia daripada raga dan jiwanya di dunia, yang berhubungan dengan penciptanya, dan bagaimana menjadi Insan seharusnya. Tujuan dari syair ini adalah mendekatkan manusia kepada Tuhan. Pertama, karena manusia tercipta dari sari pati tanah, yang nanti mereka akan kembali 
ke tanah juga. Dengan demikian, manusia senantiasa menjaga bumi, menjaga kehidupannya. Kedua, dikisahkan dalam syair ini tentang dunia dengan segala hiruk pikuk dan keindahannya, yang itu semua hanyalah ilusi dan sifatnya sementara. Maka diperingatkan manusia untuk sebaiknya menghindari hal-hal yang sifatnya duniawi. Ketiga, yang utama untuk mengingatkan diri, untuk tetap di jalan Tuhan dan menghindari sifat duniawi, adalah dengan belajar ilmu agama dengan sungguh-sungguh.

\section{DAFTAR PUSTAKA}

Al-Bayan, Vol. 22 No. 33 Januari-Juni.

Analisis Semiotik. Humaniora, Vol. XV, No. 2.

Filologi dan Analisis Semiotik. Humaniora, Vol. XIV, No. 3.

Hadi, Abdul, W.M., Ara, L.K. (1984). Hamzah Fansuri Penyair Sufi Aceh. Dalam Hadi, Abdul, W.M. (Ed.). Hamzah Fansuri: Bapak Sastra dan Bahasa Melayu (pp. 13-29). Jakarta: Lotkala.

Hamzah al-Fansuri. Tsaqofah \& Tarikh, Vol. 1 No. 1, Januari-Juni. Jentera, Vol. 5, No. 2, Desember.

Luxemburg, Jan van. (1992). Pengantar Ilmu Sastra. Jakarta: Gramedia.

Osno, Medri. (2016). Rubayat Hamzah Fansuri: Kajian Strukturalisme-Semiotika.

Pradopo, Rachmat Djoko. (2018). Pengkajian Puisi. Yogyakarta: Gadjah Mada

Rahman, Bobo Aidi. (2016). Sastra Arab dan Pengaruhnya terhadap Syair-syair

Sangidu. (2002). Sidang Fakir Empunya Kata Karya Syaikh Hamzah Fansuri: Kajian

Sangidu. (2003). Ikan Tunggal Bernama FÂDHIL Karya Syaikh Hamzah Fansuri: 
Sangidu. (2016). Tugas Filolog: Teori dan Aplikasinya dalam NaskahNaskah Melayu. Yogyakarta: Gadjah Mada University Press.

Teeuw, A. (1984). Sastra dan Ilmu Sastra. Jakarta: Pustaka Jaya.

University Press.

Zakaria. (2016). Dakwah Sufistik Hamzah Fansuri: Telaah Substansi Syair Perahu. 